\title{
Past, Present and Future of Military Food Technology
}

\author{
Chris Forbes-Ewan ${ }^{1}$, Terry Moon ${ }^{2}$ and Roger Stanley ${ }^{3}$ \\ 1. DST-Scottsdale, Food and Nutrition Group, Land Division, Defence Science and Technology, Scottsdale 7260, Tasmania, \\ Australia \\ 2. University of Sydney, Sydney, New South Wales, Australia \\ 3. Centre for Food Innovation, University of Tasmania, Launceston, Tasmania, Australia
}

\begin{abstract}
Food technology has been instrumental in ensuring that troops remain "fit to fight”. Early food technologies produced flat bread, hard biscuits, cheese and salted meat, allowing Roman legionaries to carry rations for several days. Canning was invented in the late 18th century in response to the French Government's offer of a substantial reward to the person whose invention would allow troops to carry their food when marching long distances. World War II saw further advances in the form of stable and palatable canned meals, compressed cereal bars, candy-coated peanuts and other innovative foods in US combat rations. Two significant technology breakthroughs in the second half of the 20th century have altered the form of military rations. Freeze drying matured as an industrial technology, allowing the production of long-life, light-weight rations. Flexible packaging, based on plastic laminates, led to reduced weight and less waste disposal through the development of retort pouched meals (meals in flexible packaging that have undergone heat sterilization), which have largely replaced metal cans in combat rations. Improvements in quality of military rations, particularly their organoleptic properties, are emerging through application of innovative technologies such as high-pressure thermal processing, pulsed electric field, and microwave assisted thermal sterilization. Research and development of "functional foods", such as those containing added essential fatty acids or probiotics offers the potential to provide combat rations that can further improve soldier health and performance.
\end{abstract}

Key words: Military feeding, combat rations, food technology.

\section{Introduction}

Sometimes neglected in official war histories, effective logistics has been a prerequisite to military success since organised warfare began. The availability of weapons and ammunition may be of paramount importance during battle, but in the period leading up to war-and between battles-it is the provision of adequate water and food that is the major determinant as to whether troops will be fit to fight. Early military leaders realised that how well their men were fed played a crucial role in success on the battlefield. Napoleon Bonaparte famously observed that "an army marches on its stomach"; that is, access to adequate quantities of nutritious food is a prerequisite to success in battle.

Fresh foods spoil within days or even hours of

Corresponding author: Chris Forbes-Ewan, senior nutritionist (retired), research field: military nutrition. production. This has given rise to development of technologies for preserving food. The earliest food preservation technologies-smoking and drying - even pre-date civilization. They may also pre-date all the other sciences except weapons technology. With nutritional status being central to success in battle, food technology has long been considered an enabler for military operations. Moreover, the relationship between food technology and war is two-way: the need to keep troops well-fed has also been a stimulus for the development of new food technologies.

Fig. 1 provides a timeline for military rations stretching back to $1500 \mathrm{BCE}$, capturing the major advances to date.

\section{Early Combat Rationing}

As articulated by the great Chinese military strategist 


\section{Military Rations Timeline}

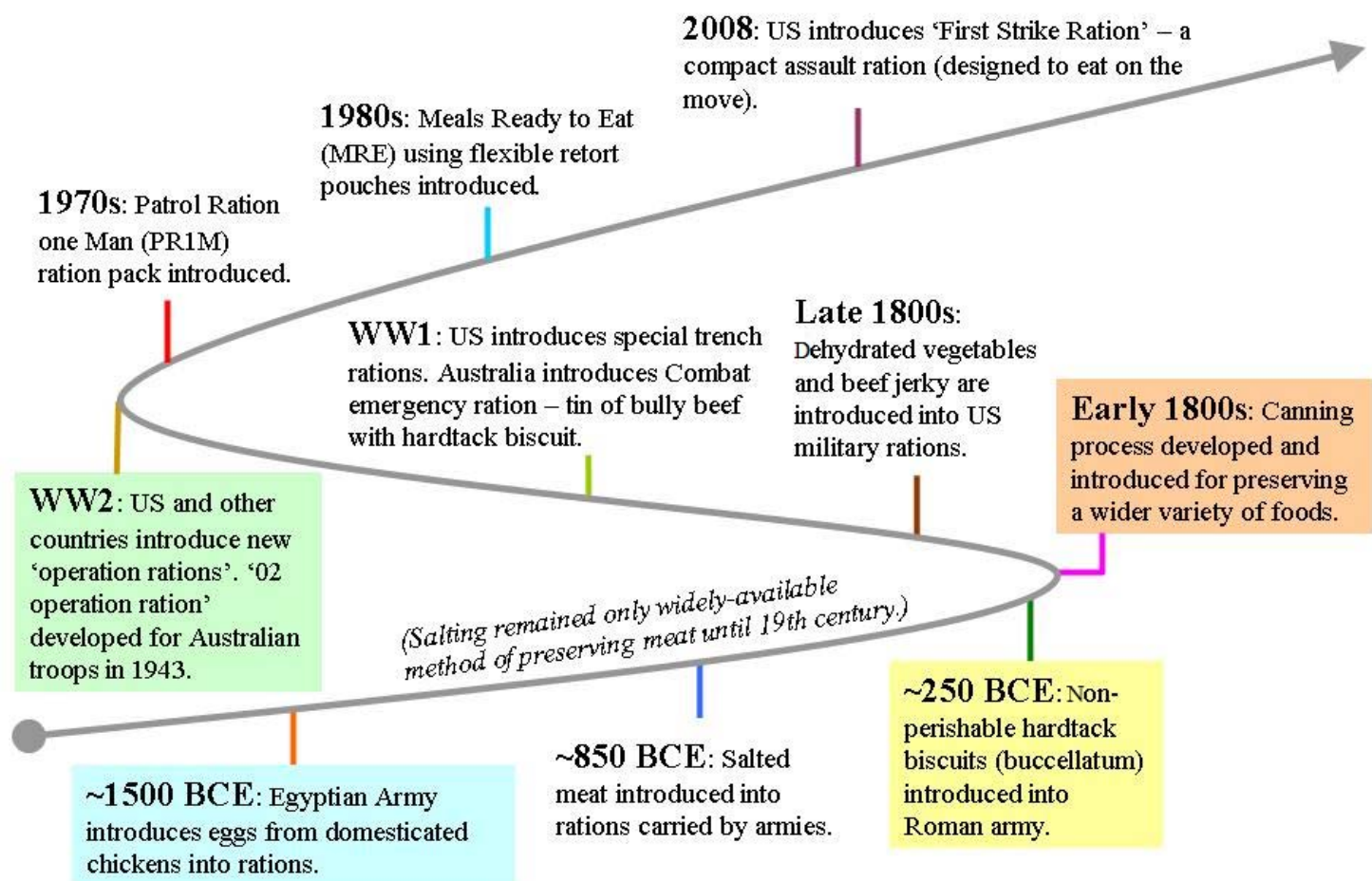

Fig. 1 Timeline of major developments in convenient, long shelf-life field rations for the military.

and philosopher Sun $\mathrm{Tzu}^{1}$, early armies usually foraged for food or plundered it from the areas they invaded. This was an uncontrolled, unpredictable approach with an uncertain outcome.

While the Ancient Egyptian army foraged much of the food they needed by systematically looting crops as they advanced, they also introduced a strategy of placing food storage depots along a campaign path. As warfare advanced, more consideration was given to feeding soldiers in the field. Following the domestication of chickens, eggs become a cheap and accessible staple of the Egyptian army. Other foods that could be easily stored and transported included onions, beans, figs, dates and some meats [1].

Ancient Greek soldiers ate fruit and vegetables supplemented with fish whenever possible. Some

\footnotetext{
1 "Bring war material with you from home, but forage on the enemy. Thus the army will have food enough for its needs"-Sun Tzu circa 500 BCE.
}

long-lasting foods were used, such as onions and thyme, together with salt [1].

Early combat feeding was further developed by arguably the most successful army in human history - that of the ancient Romans. By about 500 years after the time of Sun Tzu, the Romans had discovered that if they relied entirely on foraging, situations could arise when their soldiers would starve. Roth [2] refers to the 4th Century Roman military writer Vegetius citing the military proverb "Whoever does not provide for provisions and other necessities is conquered without fighting." According to Roth [2] "The Romans combined foraging, requisition and supply lines into the best organized logistical system the West would see for another 1500 years."

The load typically carried by Roman legionaries when marching to battle has been estimated at about $20 \mathrm{~kg}$, with soldiers expected to maintain a marching pace of about $4.5 \mathrm{kph}$ for distances of about $30 \mathrm{~km}$ [3]. 
In addition to military equipment-usually including armour, a javelin, a sword, a dagger, thick sandals, a shovel and a marching pack-each Roman legionary would typically carry several days of food, as well as cooking equipment and a bladder for water. The food would typically include "hardtack" (a simple type of cracker made from flour, water, and sometimes salt), flat bread, dried or salted meat, some wine, vinegar and salt, although other processed foods played minor roles in Roman combat rations [2].

The Roman army systematized the feeding of troops by introducing logistics for transporting quantities of food comparable in quality to that offered at their garrisons. Much as armies do today, the Romans selected rations taking account of cost, availability, portability, shelf-life stability and ease of preparation in the field [4].

As a result of this systematized approach, Roman soldiers regularly ate a variety of foods that included salted pork, sausage, ham, bacon, bread, peas, lentils, beans, olive oil and wine. However, grain is believed to have made up the bulk of the Roman soldier's diet [5]. The meat ration is estimated by Roth [2] to have been approximately $160 \mathrm{~g}$ per day. If this is cooked meat, it is comparable to modern, western intakes. For example, the average daily intake of "lean meats and alternatives” by adult Australian males corresponds to $150 \mathrm{~g}$ of cooked lean red meat or $230 \mathrm{~g}$ of cooked lean poultry (calculated from Ref. [6]).

Other animal products were also consumed by Roman legionaries-particularly cheese (caseus) made from cow's, sheep's and goat's milk. Cheese contributed not only protein, but also fat and hence energy to the Roman soldier's diet. Due to its low weight, high energy density and ease of transport, it is quite likely that cheese made up an important part of the campaign diet [2].

Olive oil was apparently also an important dietary component-according to Roth [2] “during Aelius Gallus's expedition to Arabia, the Romans were reduced to eating butter instead of olive oil, which they considered to be a hardship.”

The average weight of the daily ration is estimated to have been about $1.3 \mathrm{~kg}$, consisting of approximately $850 \mathrm{~g}$ of grains and $460 \mathrm{~g}$ of other foods. If biscuit (corresponding to "crackers" in the US) was carried instead of flat bread, the weight may have been less than $1.2 \mathrm{~kg}$ [2]. Unlike bread, which would have staled or become mouldy within a day or so, biscuit will keep for several weeks. Re-baking bread into biscuit or hardtack also reduces its weight with little loss of energy. In Late Latin, hardtack was called buccelatum (derived from bucella, meaning “mouthful”) [2].

The typical Roman ration probably provided about 3,400 kcal (14.2 MJ), and approximately $140 \mathrm{~g}$ of protein [2]. Perhaps illustrating the adage that "the more things change, the more they stay the same”, this ration was comparable to the current average NATO 24-hour individual general purpose combat ration, which provides approximately 3,750 kcal and $108 \mathrm{~g}$ of protein [7].

In addition to salting, some foods could be preserved through drying, smoking, fermenting or pickling, but all these methods significantly change the taste of food, and the food could still spoil. Despite this, the evidence suggests that the rations eaten by the Roman solider were acceptable in terms of both quality and quantity. For example, among the many complaints aired by mutinous legionaries in A.D. 14, none related to their rations. According to Roth [2] rations are "normally a commonplace of military griping”.

\section{Early 19th Century Advances in Food Technology that Influenced Combat Rations}

There was little further progress in military field rations during the Middle Ages, and it was nearly 1,500 years after the fall of the Roman Empire before the next major advance in food technology

\footnotetext{
${ }^{2}$ Translated from the French "plus ça change, plus c'est la même chose” (Jean-Baptiste Alphonse Karr).
} 
occurred - the invention of canning.

The driver for this invention was Napoleon Bonaparte's quest to conquer Europe. As his invading troops moved further from France it became clearer to the French Government that European conquest would depend partly on finding a means of preserving food so French troops could carry their rations with them, rather than having to rely on long supply lines or foraging.

The executive branch, known as the Directory, offered a prize of 12,000 francs to the person who could develop a practical means of preserving food for the army during its long forays [8].

In 1795, a French confectioner named Nicholas Appert commenced experiments aimed at winning the prize. At that time, chemistry was in its infancy, and bacteriology did not exist. (The germ theory of disease was not widely accepted until the 1860s, when Louis Pasteur, Joseph Lister and Ignaz Semmelweis conducted the seminal research in this area). Appert thus had no theory on which to base his experimentation.

Through trial-and-error he found that heating food beyond the boiling point of water $\left(100{ }^{\circ} \mathrm{C}\right)$ was effective in sterilizing food [8].

Following further refinements and a successful trial in 1806 by the French Navy on a wide range of canned foods, Appert published his findings in 1810 and was awarded the prize of 12,000 francs [9].

However, Appert's method was very timeconsuming and involved the use of glass bottles, which could break during transportation. In 1810 Peter Durand patented the use of tin-plated iron canister in place of glass jars-hence the term "can" for the product and "canning" for the process. By 1820 Durand was supplying the Royal Navy with large quantities of canned food [10].

In 1822 Appert countered with another advance - the use of cylindrical tin-plated steel cans-further increasing the shelf-life and portability of food for military use [8].
Canning thus provided the first reliable and safe method for preserving many different types of food for extended periods of time so they could be used by soldiers and sailors when deployed [11]. Importantly, much of the nutritional value, taste and appeal of food are retained through canning [12].

As the provisioning of armies took on greater importance, so the demand for processed foods grew. During the "Indian Wars" in the USA in the period 1865-1890, dehydrated vegetables such as dried onions, cabbage, beets, turnips, carrots and capsicums were developed as "trail rations".

Pemmican - a combination of dried meat and fruit developed by the plains Indians as food to tide them over winter was also adopted as a food for troops away from barracks. Jerked beef (now more commonly known as "beef jerky") and pinole (dried and ground wheat or corn) were also used [13].

In the mid-19th century the US Civil War provided impetus for further development of canning and dehydration technologies to sustain troops on the battlefield. Commercial applications of these technologies soon followed [13].

\section{The Influence of the World Wars on Combat Rations}

Improvements in combat feeding in the 20th century were largely driven by innovations emanating from the United States during World War I (WWI) and World War II (WWII).

In WWI the US Trench Ration consisted of canned food and other long-shelf-life items such as coffee, salt and sugar. The Reserve Ration provided the same food, but in hermetically-sealed containers which were to be opened only if no other food was available [14].

The combat rations we know today first came into existence during WWII, when the US Army diversified its range of operational rations.

The US Army entered WWII with two established special-purpose rations-Field Ration $\mathrm{C}$ and Field 
Ration D [13]. Field Ration C consisted of three meals, with each meal providing a 12-oz ( 350 g) can of a meat-based meal, biscuits, chocolate and soluble coffee. Shortly before the entry by the US into WWII, individually wrapped hard candies and chocolate caramels were added to the C Ration. Field Ration D consisted of three 4-oz $(\sim 120$ g) bars made of chocolate, sugar, oat flour, cacao fat, skim milk powder and artificial flavoring.

Among several other special-purpose combat rations, the Assault Lunch satisfied the need for a small, lightweight and concentrated ration to provide assault troops with an easily-carried prepared food which would bridge the gap between the beginning of actual combat and the restoration of normal supply functions [13]. As such, it might be considered the forerunner of the US Army's current First Strike Ration [14].

In Australia, the first combat ration (designated the “O2 Operation Ration”) was developed in 1943. This ration provided adequate nutrition (both energy and micronutrients) for troops engaged in normal operations and played a significant role in the successful Australian campaign in New Guinea [15]. The contents of the Operation Ration O2 are shown in Table 1.

These WWII rations were the forerunners of modern combat rations, which are designed to meet four criteria: appropriate nutritional value and balance; adequate stability when stored and transported under challenging conditions; suitable packaging for convenience and carriage; and adequate palatability to ensure a high level of consumption [16].

\section{Post WWII Advances in Combat Rations}

Three innovations in food technology of special value to the military occurred after WWII-flexible packaging, retort pouches and freeze drying. The availability of these technologies brought about significant changes in military rations worldwide.

(1) Flexible Packaging: The early 1960s saw a significant development in flexible packaging materials, with multilayer films first becoming available. These contain a combination of materials that consist of one or more layers of plastic polymers, aluminium foil, nylon, or paper that are bonded together. Each layer either contributes to strength or provides a barrier to moisture or air. Consequently, combat ration food items had longer shelf lives than equivalent commercial foods [17].

(2) Retort Pouch: This was developed by the US Army as a replacement for metal cans [18]. The technology involves the use of three or four layers of heat-resistant flexible packaging materials laminated together to create an impermeable barrier. Because it has a thinner profile than the tin-plated steel used for canning, and can be massaged to mix the contents, there is more efficient heat transfer. This significantly

Table 1 Contents of the WWII Australian Operation Ration O2.

\begin{tabular}{|c|c|c|}
\hline Meal 1 & Meal 2 & Meal 3 \\
\hline Carrot biscuit $3 \mathrm{oz}$ pkt & Wholemeal biscuits $2 \frac{1}{4} \mathrm{oz}$ pkt & Wholemeal biscuits $2 \frac{1}{4} \mathrm{oz}$ pkt \\
\hline Fruit \& Nut $3^{3} / 8$ oz block & Wheat Lunch 3 oz block & Chocolate 3 oz block \\
\hline Meat \& Vegetable Stew 4 oz tin & Meat \& Vegetable Hash $4 \mathrm{oz}$ tin & $\begin{array}{l}\text { Meat \& Beans OR } \\
\text { Corned Beef Hash } 4 \text { oz tin }\end{array}$ \\
\hline Peanut butter $1 \frac{1}{2} \mathrm{oz}$ tin & Cheese $1 \frac{1}{4} \mathrm{oz}$ tin & Blackcurrant Spread $1^{7 /} 8 \mathrm{oz}$ tin \\
\hline Barley Sugar Rolls (4) $1 \mathrm{oz}$ & Barley Sugar Rolls (4) $1 \mathrm{oz}$ & Barley Sugar Rolls (4) $1 \mathrm{oz}$ \\
\hline Caramel Bar $1 / 2 \mathrm{Oz}$ & Lime Tablets $1 / 2$ oz pkt & Caramel Bar $1 / 2 \mathrm{oz}$ \\
\hline Skim Milk Powder $1 / 4$ oz pkt & Skim Milk Powder $1 / 4$ oz pkt & Skim Milk Powder $1 / 4 \mathrm{oz}$ \\
\hline \multirow[t]{3}{*}{ Sugar 2 Tablets } & Sugar 2 Tablets & Sugar 2 Tablets \\
\hline & Tea 4 Tablets & Tea 4 Tablets \\
\hline & Salt 2 Tablets & Salt 2 Tablets \\
\hline
\end{tabular}

Source: Ref. [15]. 
reduces the adverse effects on food components-particularly sensory properties and nutritional quality—of long cooking times at high temperatures. Also, because the retort pouch is more compact and lighter than the rigid can, it reduces both bulk and load carriage. The Meal, Ready-to-Eat (MRE)—based on retort pouch technology-was prototyped in the US in 1970 and introduced into service in the 1980s [14].

(3) Freeze Drying: This process was first patented in 1945 by Jay Hormel to make preserved foods [19]. It involves cooking the meal, quickly freezing it, and then placing the frozen food in a chamber under high vacuum-typically about a thousand times less than air pressure-and gentle heating. Under these conditions the ice crystals sublime directly to gas until a very dry, solid food with microscopic pores remains. Unlike the situation with conventional hot-air drying, there is minimal alteration of the physical structure of the food, and nutrients are better retained. The food therefore rehydrates more readily, retains more flavour, and the very low moisture $(<2 \%$ by weight) inhibits both microbial and mould growth, giving the food a long shelf life even at elevated storage temperatures. Removal of most of the water content of the food also results in an ultra-lightweight meal.

\section{Current and Likely Future Developments in Military Food Technology}

In the early 21st century the US remains a leader in developing and adapting food-related technologies for military application.

Among technologies that were recently developed and are being studied for their potential to enhance combat feeding are pulsed electric field (PEF), microwave assisted thermal sterilization (MATS) and high-pressure processing sterilization (HPS). These technologies are capable of producing high-quality combat ration foods that have undergone less heat degradation than traditional thermal retort processes. Consequently, they have higher nutritional quality and better organoleptic properties.

PEF applies pulses of high voltage to food placed between two electrodes for periods of around one second. This leads to inactivation of micro-organisms, while minimising the energy required for processing foods [20]. PEF has been trialled for combat rations, but requires further development to be fully proven under commercial conditions [21].

MATS technology uses $915 \mathrm{MHz}$ microwave energy to penetrate and rapidly heat the packaged food. It has been developed for military applications by Washington State University and pilot machinery is being used commercially to make trial products [22].

HPS has been derived from High Pressure Pasteurisation (HPP) by using higher temperatures, pressures and times to achieve greater inactivation of spores than can be achieved by HPP. The combination of pressure and temperature inactivation can achieve sterilization with less degradation than thermal processing alone. MREs can be sterilized in their packaging.

However, the industrial machinery to achieve the conditions is capital-intensive and also still undergoing development [23]. Hay and Slater [24] discuss the potential for these new technologies to enhance naval victualling.

In concert with the development of sterilization technologies is the introduction of Continuous Product Improvement (CPI) concepts in both the USA and Australia. CPI has seen the steady improvement of combat rations whereby items are replaced or upgraded depending on feedback from soldiers, and on a structured program of sensory evaluation of ration food and beverage items.

Consistent with CPI is the trend towards making greater use of "functional foods", i.e. foods that are designed not only to provide basic nutritional needs but that have also been modified to deliver specific health benefits. Two examples are the use of probiotic bacteria to maintain digestive health [25], and the incorporation of omega-3 fatty acids for reducing 
inflammation and maintaining mental health [26].

\section{General Discussion}

For at least 2,500 years it has been recognised that access to adequate quantities of nutritious food is an enabler of success in war. In modern military terms, food is seen as a "force multiplier".

As a result of advances in food technology, particularly in the past 200 years, troops have been provided with long-shelf-life foods of continually improving quality (both in terms of nutritional value and acceptability).

Nutritional quality and acceptability of rations are both vital to ensure that troops achieve optimal military performance. Nutritional quality is essential to ensure the potential for high nutritional status of troops. But achieving high nutritional status is also dependent on troops actually consuming the rations - uneaten food is of no nutritional value-hence it is also critical that the food in combat rations is highly palatable. Troops will habitually discard substantial proportions of their combat rations, with its acceptability (or a lack thereof) cited as a significant factor. Even if hungry, troops will commonly discard food they do not like [27].

Meiselman [28] identifies variety as another factor that affects the consumption of combat rations - the greater the variety, the greater the likelihood that adequate food will be consumed, and the better the health and performance of the soldier.

One major factor restricting the variety of food available to troops in the field is the limited shelf life of many processed foods. Most nations have strict requirements for shelf life of combat rations. As examples, Australia's general purpose combat ration (Combat Ration One Man) is required to have a shelf life of 24 months when stored at $30^{\circ} \mathrm{C}$, while the US Army specify a shelf life of 36 months at $27^{\circ} \mathrm{C}$ for the MRE [7]. Current food technologies do not always produce foods that meet these criteria.

Among the new technologies described previously,
MATS in particular shows the potential to produce foods that not only retain a high proportion of the initial nutritional value, but also a high level of acceptability for several years after manufacture. The advent of functional foods also shows promise for improving soldiers' health and performance during periods when they rely exclusively on combat rations for food.

In conclusion, there has been a two-way interaction between food technology and the waging of war for more than two millennia. War has often been a trigger for the development of new methods of food processing which are then found to have commercial application. Conversely, new commercially valuable technologies have sometimes been successfully adapted to the military situation. This symbiotic relationship between war and food technology is set to continue into the foreseeable future.

\section{References}

[1] Eden, L. 2011. "An Army Marches on Its Stomach: An Analysis of the Ancient Soldier's Diet.” Accessed July 2, 2016. http://lilitheden.hubpages.com/hub/An-Army-MarchesOn-Its-Stomach-An-Analysis-of-the-Ancient-SoldiersDiet.

[2] Roth, J. P. 1999. "The Logistics of the Roman Army at War (264 B.C.-A.D. 235).” Brill, Boston. ISBN 9004 112715.

[3] Whipp, B. J, Ward, S. A., and Hassall, M. W. C. 1998. "Paleo-Bioenergetics: The Metabolic Rate of Marching Roman Legionaries.” British Journal of Sports Medicine 32: 261-4.

[4] Food Timeline, 2015. "Ancient Romans Soldiers Mess.” Accessed July 22, 2016. www.foodtimeline.org/restaurants.html\#romansoldiers.

[5] Alcock, J. P. 2006. Life in Roman Britain. Stroud, UK: Tempus Pub Limited.

[6] Australian Bureau of Statistics. 2016. "Australian Health Survey: Consumption of Food Groups from the Australian Dietary Guidelines, Australia 2011-12.” p. 29. ABS Catalogue No. 4364.0.55.012. Accessed Aug. 3 ,

2016. http://www.ausstats.abs.gov.au/Ausstats/subscriber.nsf/ 0/12E8766EBAB492B0CA257FAF001A3CFD/\$File/4 3640do002_20112012.pdf.

[7] NATO. 2010. "Nutrition Science and Food Standards 
for Military Operations.” Annex E. RTO Technical Report, TR-HFM-154: Final Report of RTO Task Group RTG-154. Research and Technology Organisation of the North Atlantic Treaty Organisation. ISBN 978-92-837-0097-5. Accessed Jul. 18, 2016. http://www.dtic.mil/dtic/tr/fulltext/u2/a526318.pdf.

[8] Encyclopedia of World Biography. 2004. Accessed July 1, 2016. http://www.encyclopedia.com/topic/Nicolas_Appert.as px.

[9] Encyclopaedia Britannica (undated a.). Encyclopaedia Britannica Online. Accessed July 9, 2016. http://www.britannica.com/EBchecked/topic/30573/Nic olas-Appert.

[10] Encyclopaedia Britannica (undated b.). Encyclopaedia Britannica Online. Accessed July 10, 2016. https://www.britannica.com/topic/canning-food-process ing\#ref135266.

[11] Valigra, L. 2011. "The Father of Food Preservation: Nicholas Appert Invented Techniques for Long-Term Food Storage.” Food Quality \& Safety Magazine, February/March.

[12] Couture, L. 2010. "The History of Canned Food." Johnson \& Wales University, ScholarsArchive@JWU, 28 April. Accessed July 9, 2016. http://scholarsarchive.jwu.edu/cgi/viewcontent.cgi?artic le=1006\&context=ac_symposium.

[13] US Army Quartermaster Foundation (undated). “Army Operational Rations-Historical Background.” Accessed July 2, 2016. http://www.qmfound.com/army_rations_historical_bac kground.htm.

[14] US Army RDECOM. 2015. "Operational Rations of the Department of Defense.” Natick PAM 30-25, 10th Edn, February 2015. Accessed Aug. 3, 2016. http://nsrdec.natick.army.mil/media/print/OP_Rations.p df.

[15] Stanton Hicks, C. 1972. Who Called the Cook a Bastard? Sydney: Keyline Publishing.

[16] Rees, J. U. 2002. "The Foundation of an Army Is the Belly: North American Soldiers' Food, 1756-1945”. Accessed July 26, 2013. http://revwar75.com/library/rees/belly.htm.

[17] Forbes-Ewan, C., and Racicot, K. 2013. "Feeding in the Field: Past, Present and Future.” In Proceedings of the 46th Annual AIFST Convention, Brisbane, Australia, July 14-16.

[18] Lampi, R. A. 1981. "Retort Pouch: The Development of A Basic Packaging Concept in Today's High Technology Era.” Journal of Food Process Engineering
4: 1-18.

[19] Hormel, J. C. 1945. Process for Preservation of Biological Materials and Products Resulting therefrom. Patent US 2388917 A.

[20] FDA (undated). "Kinetics of Microbial Inactivation for Alternative Food Processing Technologies-Pulsed Electric Fields.” US Food and Drug Administration. Accessed July 15, 2016. http://www.fda.gov/Food/FoodScienceResearch/SafePr acticesforFoodProcesses/ucm101662.htm.

[21] Dunne, C. P., Dunn, J., Clark, W., Ott, T., and Bushnell, A. H. 1996. "Application of High Energy Electric Field Pulses to Preservation of Foods for Combat Rations." Science and Technology for Force XXI. Department of the Army. Norfolk, Virginia. June 24-27.

[22] Foran, A. 2012. "MATS-B Microwave Installed at AmeriQual Assists CFD at Natick.” Accessed Aug. 4, 2016.

https://www.army.mil/article/87943/MATS_B_microw ave_installed_at_AmeriQual_assists_CFD_at_Natick/.

[23] Barbosa-Cánovas, G. P., and Juliano, P. 2008. "Food Sterilization by Combining High Pressure and Thermal Energy." In Engineering: Integrated Approaches, edited by Gutierrez-Lopez, G. F., Welti-Chanes, J., and Parada-Arias, E. Springer, 9-46.

[24] Hay, T., and Slater, K. 2014. "Victualling for Future Royal Australian Navy Platforms-Alternative Technologies.” DSTO-TN-1379. Land Division, Defence Science and Technology Organisation Accessed Jul. 2016. http://www.dtic.mil/cgibin/GetTRDoc?AD=ADA61681 1.

[25] Radway, K. 2008. "Live Bacteria Called to Active Duty: U.S. Military Doing Clinical Trials on Probiotics-Fortified Foods.” Accessed Jul. 18, 2016. http://newsarchive.medill.northwestern.edu/chicago/ne ws-94807.html.

[26] Davis, A. B., and Prall, B. C. 2014. "The Challenges of Incorporation of Omega-3 Fatty Acids into Ration Components and Their Prevalence in Garrison Reeding.” Military Medicine 179 (11): 162-7.

[27] Marriott, B. M. 1995. Not Eating Enough: Overcoming Underconsumption of Military Operational Rations. Washington, D.C.: National Academy Press.

[28] Meiselman, H. 2010. Behavioral/Psychological Assessment Summary. Chapter 5 of Nutrition Science and Food Standards for Military Operations. RTO Technical Report, TR-HFM-154: Final Report of RTO Task Group RTG-154. Research and Technology Organisation of the North Atlantic Treaty Organisation. 